\title{
VIGILANTE GROUPS AND POLICING IN A DEMOCRATIZING NIGERIA: NAVIGATING THE CONTEXT AND ISSUES
}

\author{
Adeniyi S. Basiru ${ }^{1}$ \\ Olusesan A. Osunkoya²
}

\section{Introduction}

Before the advent of colonialism in Nigeria, the various indigenous communities, like elsewhere in Africa, had evolved various self-help institutions (vigilante groups in modern sense) for maintaining public order. But, with the emergence of the colonial state and all its coercive paraphernalia, these traditional institutions of public order management, that had for centuries served the people, were relegated to the background, as the modern police force, the precursor of the present day Nigerian Police, under the direction of the colonial authorities, became the primus inter pares, in the internal security architecture of the colony (Ahire, I99I, I8). With this development, the communal/collectivist-oriented frameworks of policing that had for centuries been part of people's social existence now constituted the informal models of policing rendering subsidiary roles.

For decades, this was the arrangement for policing the vast Nigerian territory. Although, there were documented cases of police re-organizations, by the colonial authorities, in Lagos, in I930 and I954 (Akuul, 20II, I8), these, however, neither reversed the western-dominated order of policing nor re-organized the indigenous informal models of policing. Put differently, the indigenous police institutions, in differently parts of the country, continued to play subsidiary roles in public order management. Instructively, at independence, the colonial arrangement rather than being transformed to reflect

I Department of Political Science, University of Lagos, Lagos, Nigeria. E-mail: asbash72@ yahoo.com

2 Department of History and Diplomatic Studies, Tai Solarin University of Education, Ijagun, Nigeria. E-mail: osunkoyaoa@tasued.edu.ng 
the country's new status, as a sovereign nation, was further strengthened by the post-colonial ruling elites (Chukwuma, I998, 26).

However, as the country evolves politically, socially and economically, aside being confronted with legion of socio-economic and political challenges, it has also been confronted with myriads of violent crimes some of which have posed serious threats to its survival (Otto; Ukpere, 20I2, 52). Unfortunately, the responses of the Nigerian Police Force, the formal policing establishment, to these challenges, despite continuous flow of funds from the governments at the federal, state and local levels, would appear to have been less than optimal. Perhaps, this circumstance prompted the Federal Government to establish the Nigeria Security and Civil Defence Corps (NSCDC) and other law enforcement agencies to assist the Nigerian Police Force, in the process of law enforcement and maintenance of order in the country (Wisler; Onwudiwe, 2005, I3).

Yet, the environment of public policing in the country, in the last few years, despite the measures put in place by the Federal Government, seems not to have fared better, as incidences of crimes, including those of lethal proportions, increased at all corners of the nation (Alemika;Chukwuma, 2004, I4). More worrisomely is the seeming lethargic attitude shown over the years, by the Federal Government, towards salvaging public policing in the country (Jemibewon, 2003, I3).At a point, state governments that did not have constitutional roles in public policing, had to step in to salvage public policing in the country by providing funding and other logistical supports to the Nigerian Police Force ${ }^{3}$. Even in spite of these, crisis of public policing in the country continue to fester (Adebakin and Raimi, 20I2, 8). Remarkably, the seeming ineptitude of the Federal Government to effectively deal with the crisis of public order management would appear to have compelled the citizens to resort to self-help measures and whereupon, vigilante groups of various genres, once vilified, proliferated throughout the country (see Baker, 2002; Higazi, 2008; Adamu, 2008). In contemporary Nigeria, the issue seems no longer to be whether these groups should exist or not, but what would become of security at the national level if they are put out of existence (Kwaja, 20I4, 5). Indeed, in the last few years, it is an incontrovertible fact that many state governments have not legalized vigilante groups to bolster the security of lives and properties in the states ${ }^{4}$.

\footnotetext{
3 For instance, the special crime fighting outfit, Rapid Response Squad (RRS), since the return of democracy in I999 has been funded by Lagos State Government.

4 For example, the Kaduna State House of Assembly, on June 6, 20I3, promulgated the State Vigilante Service Law, which legalized the operation of vigilante groups.
} 
However, in spite of their growing numbers and seeming popularity, especially since the return of democracy in I999, issues are constantly being raised regarding whether they could really be agents of democratic policing, against the background of their penchants for wanton violence, human rights violations and extra-judicial killings (see Amnesty International, 2002; HRW/ CLEEN, 2002). To this end, there have been increasing concerns in policy and academic circles if vigilante groups are not themselves threats to the security not only of the communities where they operate but the country as a whole. In addition, in contemporary times the country is battling its worst level of insecurity since the civil war, which ended in I970. It is against this background this article examines the place of vigilante groups in Nigeria's policing environment since the return of democracy in I999. What have been their roles in post-authoritarian Nigeria? In discharging these roles, have they really constituted themselves as security threats to the country fledgling democracy? Specifically, this article engages these questions within the framework of the objective of the study.

In terms of organization, the article is partitioned into six sections, starting with an introduction pointing to the study's purpose, significance and rationale. Section two presents the conceptual framework that guides the discourse in the article. The third section, in a retrospective fashion, looks at the evolution of vigilante groups in Nigeria. The aim here is to lay bare the dynamism of vigilante groups in modern Nigeria. Section four critically examines the roles of vigilantes and other informal policing groups in public order management in the post-I999 era, with illustration of two cases. In section this follows, the performance of vigilante groups in contemporary era are assessed in the context of the country's security environment. Section six rounds up with a few submissions.

\section{Policing, Police, Vigilantism and Vigilante Groups: A Con- ceptual Discourse}

Frankly speaking, the four concepts that are central to this article, policing, police, vigilantism and vigilante groups, indeed, like their peers in security studies cannot be pinned down to one specific definition as they conjure different meanings. In other words, they are, to borrow Gallie's (I962) elegant phrase, essentially contested concepts. To this end, the approach that is adopted in this article is to conceptualize and discuss their meanings from the perspective of the nexus connecting them. Firstly, the concept of policing, 
here defined as the process of safeguarding the individuals and groups in a community, it must be stressed, is old as the man itself. Indeed, even in the pre-state social formation in which life was nasty, brutish and short, as Hobbes and other the social contract philosophers theorized, policing, even though egocentric, was an integral part of the social processes.

However, the concept assumed modern connotation, wider acceptability and popularity against the background of the monumental disorder arising from population explosion, urbanization, and industrialization brought about by modernity, which led to the advent of the Weberian centralized state structures. Consequently, policing, which has now acquired public character, did not only emerge as the key parameter for defining Weberian statehood but, most importantly, as activities undertaken by specialized body of men established by law (Loader, 2000,325 ). In the words of Alemika and Chuckuma $(2004,2)$, 'the emergence of the state as an entity with claim to the monopoly over the means of legitimate violence in society resulted into the creation of specialized agencies such as the police'. In this wise, police is defined in relation to modern statehood. According to the Oxford Dictionary of Current English, edited by Catherine Soanes (2001, 692), police is defined as an official group of people employed by state to prevent and solve crime and keep public order. In their contribution to the meaning of police, Alemika and Chuckuma $(2002,3)$ sees police as a socio-political and quasi-legal institution-state agencies charged primarily with the enforcement of criminal law and the maintenance of order. The duo further adds that definition of police go beyond the constabulary sector to include other state agencies that are also involved in fighting crime and maintenance of law and order, such as the Customs and Immigration.

The point being made here is that the concept of policing differs conceptually and analytically from that of police, even though, the duos are part of the social control processes. The former broadly depicts control mechanisms deployed by societal institutions, state and non-states, to regulate the conduct of individuals and groups in order to bring them in conformity with acceptable norms and values. In other words, policing does not only entail law and order maintenance through the instrumentality of the state (public policing) but also through other non-state actors. Framed in this context, therefore, the police, the institutional edifice for operationalizing public policing, is one of the several strategies deployed by modern societies to maintain law and order (see Johnston I992). Indeed, it is this wise that Baker (2008) and Lar (2015) in their notions of plural policing and multi-choice policing contend that in modern societies, diverse networks of groups-commercial bodies, voluntary and community groups, individual citizens, national and local governmental 
regulatory agencies, as well as the public police deliver policing services to the citizen. Specifically, it is in lieu of this broad conceptualization of policing that the concept of vigilantism and by extension, vigilante groups seem to derive their conceptual significance.

However, it is to be stressed that the concept of vigilantism, in modern policing literature, though in the last few decades has assumed wider popularity, conjures up divergent interpretations. As Lar $(2015,54)$ rightly affirms, 'there is as yet no scholarly consensus on what vigilantism is - especially as regards the nature of its relationship with the state'. But for the purpose of this article, Fourchard's perspective is apt. In relation to policing, he opines that, vigilantism is "an organized attempt by a group of ordinary citizens to enforce norms and maintain law and order on behalf of their communities, often by resorting to violence, in the perceived absence of effective official state action through the police and courts' (Fourchard, 200I, 609). Viewed this way, vigilantism would depict organized efforts on the parts of citizens (individual and corporate) towards fighting criminal activities that threaten social order at the sub-state level. Flowing from the foregoing, vigilante groups would, thus, appear to suggest a voluntary group of individuals organized, usually at the communal/provincial level, for the purpose of policing. In the context of the above, therefore, it may be posited that not all groups that parade themselves, especially in contemporary Nigeria, as vigilantes are, conceptually, so. Reinforcing this contention, Shaw $(2000,48)$ posits that,

care must be taken not to generalize on the subject of vigilante groups. Some seek to provide due process for arrested criminals in the absence of any viable state institutions in many areas. Some of the groups that have been labeled as vigilante groups range from neighborhood watches, communal guards, age grades, masquerade cults to hunters' guilds.

In the context of the foregoing and for the purpose of this article, therefore, vigilante groups are conceptualized loosely, following Alemika and Chukwuma (2004, I4), as a generic term in describing the different types of sub-state policing system of a country. In the Nigeria's informal policing system, Chukwuma (2002, II,I2), identifies four typologies of vigilantism and vigilante groups, vis: religious, ethnic, state-sponsored and neighborhood/ community. 


\section{Vigilante Groups and Vigilantism in Nigeria: Origin and Evolution}

It has to be stressed that the idea of vigilantism and by extension, existence of vigilante groups, predated the Nigerian state (Pratten, 2008, I). Indeed, the conclusion in most studies on the evolution of policing in Nigeria is that vigilantes of all shades, performing a myriad of policing functions in their communities, preceded the establishment of the colonial police (see Tamuno, I970; Tamuno et al., I993; Nwanze, I999; Rotimi, 200I). For instance, in the eastern part of the country, before the advent of modern police establishment, there existed groups known as 'Ndinche' (community guards). They were put in place by villagers to arrest and bring suspected criminals before the 'Amala' (village council) for trials. As a matter of fact, Ndinche like the 'Olodes' (Hunter Guild) and the 'Yan Banga' in the western and northern parts respectively, for centuries, superintended public order management in the various jurisdictions (Ogbozor, 20I6, 3).

However, it has pointed out that irrespective of the modus operandi of these indigenous pre-colonial vigilantes, they were structured within each community's existing political structures and values. Fourchard (20II), in an insightful study of vigilante structure in pre-colonial Yorubaland, with reference to Ibadan, recounts an interview with a respondent thus:

there was a chain of transmission of orders coming from the Olubadan ${ }^{5}$ and from heads of powerful lineages associated to the Olubadan (the Mogaji ${ }^{6}$ ) who transmitted information to heads of compound (Baale). The Mogaji were in charge of sode; they will call the head of each household, then they will tell them about the need to keep watch on the surroundings. In each household, the Baale will volunteer at least one or two people.

The point here is that the indigenous vigilante groups, before the foray of colonialism into the various communities that were later amalgamated to become Nigeria, did not operate in a vacuum but interfaced with the various communities to provide policing to their people. In other words, they functioned as self-help entities at the peripheral level of the communities (towns/kingdoms), assisting 'stately' institutions in discharging policing duties. For example, in pre-colonial Hausa Emirate state system, the vigilantes at the local level complemented the Dogaris-palace police-in maintaining law

5 Olubadan refers to the title of the paramount head of Ibadan.

6 Mogaji is the head of an extended family comprising many households in Ibadan. 
and order within the Emirate. Similar patterns operated among the Ijebus, a Yoruba sub-ethnic group, in which the various vigilantes complemented the Odis-palace police in policing the centre and the peripheries of the Ijebu state system under the Awujale? It is worthy to note that this dual system of policing involving the vigilantes and the Kings' police was, however transformed by colonial rule, which added another framework of policing leading to a tripartite system involving the vigilantes, the palace police and the colonial police.

It must be stressed, however, that in spite of their relegation to the background in the colonial tripartite policing architecture, vigilante groups continued to attract the patronages of the people in various communities, as a result of growing crime rates brought about by rapid urbanization (Watson, 2003, 76). For example, in Ibadan and other Yoruba communities, in the second half of the $20^{\text {th }}$ century, the night guard system (vigilantes), that had been suppressed, for decades, by colonial officials for being 'dangerous', was re-invigorated, under strict supervision. Fourchard (20II, II) adumbrates the five guidelines that a Colonial Resident in I948, in Oyo, gave for the operation of the night guards within his domain as follow:

- That a roster of Night Guards is kept.

- That a head hunter is appointed whose duties are to supervise the arrangements made and be responsible to the local Baale (Chief) for the conduct of the guards.

- That each hunter guard is clearly informed that firearms must only be used in self-defense.

- If a hunter guard catches a thief or suspect, he should take him to the nearest Police station at once and hand him over to the police.

- That no form of uniform is used by hunter.

Instructively, this was the model of vigilantism in most communities before the country's independence in I960. Put differently, vigilante groups like the Night Guard system in the Oyo Province, mentioned above, while being allowed to operate because of the limited coverage of the colonial policing apparatus, were strictly under the supervision of the colonial authorities. However, with the attainment of independence in 1960 , the character of vigilante groups changed from those established to promote community interests to those that now served the interests of the dominant party in the three regions of the country. For example, in the Western Region, the night

7 Till date, this is the title of the paramount ruler of the Ijebu Kingdom. 
guards and other informal policing groups, especially in Ibadan, the seat of the regional government, became instruments of political intimidation and harassment of perceived political opponents by the Akintola-led government, until the fall of the Republic on January I $5^{\text {th }}$, I966 (Rotimi, 200I, I40; Fourchard, 20II, I7).

Indeed, for the complementary roles that these vigilante groups played, especially in the Western Region, in instigating the collapse of the first republic, the new military regime, upon assuming power, did not only suppress the politicized vigilante groups but also guillotined their authority to vigilantism. Although, in the I970s, due to the oil boom which led to rising incidence of armed robbery and other allied crimes, there were increasing proliferation of neighbourhood watches and guard companies, the dispositions of the military regimes that superintended the country during the period, towards vigilante groups appeared not have changed. But, by mid the I980s, the volte face attitude of the military juntas towards vigilantes and other informal policing groups in the country changed. On why this changed attitude should not detain us here as there are abundant of studies (see Fabiyi, 2004; Fourchard, 20II).

Specifically, in I986, the Federal Military Government of Nigeria, through its representatives at the state levels, in order to improve the battered image of the Nigerian Police Force, formally embraced vigilante groups as part of the country's policing structure. In April I987, in Oyo State, the Military Governor, Col. Adetunji Olurin, by virtue of the Mobilization Community Development Committee Edict (1987), gave legal backing to vigilantism in the state when he officially launched vigilante groups (OYSG, I987). Legitimizing vigilantism, the Governor had said, 'unlike the previous vigilante groups, the activities of the groups being inaugurated were protected by the law' (see Tribune, 07/04/87). With such terse statement coming from a key member of a military junta, the environment of vigilantism in the country would appear to have changed, whereupon, the number of groups engaged in vigilantism, across the country increased. Interestingly, it was, perhaps, this legacy of government's tacit support for vigilante groups that snowballed into the fourth republic that commenced on May $29^{\text {th }}$, 1999. 


\section{Vigilante Groups and Democracy in Post-Authoritarian Nigeria}

On the $29^{\text {th }}$ May, I999, Nigeria joined the league of electoral democracies. Prior to this date, the country had suffocated under various autocratic regimes that repressed, suppressed and denied the people of their democratic rights (Ojo 2004, I54). As the newly elected President, Olusegun Obasanjo (I999), in his inaugural speech, put it:

Today, we are taking a decisive step on the path of democracy. We will leave no stone unturned to ensure sustenance of democracy because it is good for us. It is good for Africa, and it is good for the world. We call on the world, particularly the Western World to help us sustain democracy by sharing with us the burden or debt which may be crushing and destructive to democracy in our land.

With such terse remark coming from the first President of a redemocratized Nigeria, the citizens seemed to have been greeted with great hopes and expectations that an atmosphere of peace and stability, built on the foundation of democracy and good governance has come to stay in their country (Basiru, 20I6, 4). Put differently, an atmosphere in which the central state and its institutions, most especially those responsible for criminal justice, are alive to their historic mandates of dealing with crimes that could jeopardize peaceful co-existence. Specifically, the Nigerian Police, in line with Section 4 of the Police Act CAP 359 of the Laws of the Federation of Nigeria (I990), were expected to be a key player in the criminal justice system. The organization is charged with the responsibilities for detecting and preventing crime in the society.

However, within the shortest possible time, people's expectations of democratic dividends in terms of improved security environment would appear to have been dashed as some of the divisive and violent tendencies that had long been suppressed by the military juntas, while they reigned, resurfaced and became the defining characteristics of the new democracy (Jemibewon, 200I, 30). Indeed, during the first decade of the country's democratization, democracy, by some commentators, was almost assumed to be coeval with violence and insecurity. To be sure, violent crimes such as serial bombings, hostage taking, kidnapping, armed robbery, and ethno-religious violence of various genres, became regular features of the country's security landscape (see Umede, 20II, I8). As stated earlier, the Nigerian Police Force were overwhelmed and overburdened, leading to increasing roles for vigilante 
groups (Ikoh, 20I3, 48). As Jones $(2008,4)$ notes, 'vigilante groups in Nigeria were created in response to the security vacuum left by the impotent state and its security forces'. What is being pointed out here is that, democracy, aside offering avenues for wider citizens' participation in public affairs, has also created opportunities, due to the declining capacities of the police to manage growing insecurity, for increasing participation of the vigilante groups in policing democracy.

It has to be stressed, however, that in vigilanting democracy and the demos since the beginning of the fourth republic in Nigeria, some vigilante groups, especially, those governed by formal rules, in major cities, would appear to have performed well in the complementing the formal policing structures. On the other hand, some would seem not to have fared better in vigilanting democracy as in the cases of those with conflicting agenda (Akubor 20I4). The cases of the Bakassi Boys and O'odua People's Congress (OPC) that are presented in the proceeding paragraphs typify such vigilante group.

\section{The Bakassi Boys}

The Bakassi Boys serves as an empirical illustration of the perversion of what vigilantism is by a vigilante group, in a country that transited from authoritarianism into electoral democracy. There are two reasons why the case of the Bakassi Boys is apposite and lends itself to inquiry on the activities of vigilante groups in a democratizing society. First, the groups is, perhaps, the first vigilante group in post-Authoritarian Nigeria that was formed by artisans and later to be hijacked by state governments. Second, it was the first vigilante group in post-Authoritarian Nigeria that drew the attention of the Federal Government and the international community to the danger that vigilante groups could pose to the security of the country. That stressed, Bakassi Boys, like other dreaded vigilante groups that emerged after the departure of the military from the political scene in I999, came on board as the direct consequences of armed robbery in the major markets in the South-east, especially, in Aba, Abia State (see Baker 2002; Harnischfeger 2003; Smith 2004).

Prior to its formation, Aba, the commercial nerve centre of Abia State, were under the 'government' of a notorious armed robbery gang, nicknamed 'Mafia' which terrorized traders in the major markets in the town. Instructively, while the gang reigned, the Nigeria Police Force (NPF) seemed impotent in curtailing and arresting this situation. The seemingly impotence of the 
Police forced the traders and the artisans in the markets to resort to self -help in order to confront the dreaded gang which they eventually defeated. Specifically, the group arose, in I998, following a gruesome murder of a prominent trader in Aba market which forced the traders to, spontaneously, embarked on an operation of seizing and executing suspected armed robbers, until nearly all suspected criminals had been executed or had fled the state (Jones, 2008, 2).

Perhaps, this feat of eliminating the dreaded Mafia convinced the major stakeholders in the markets around Aba that the messiah had finally arrived. At this stage, they realized the imperative of transforming the loosely organized entity into a permanent organization and by so doing, earning stipends from their patronizers. Thereafter, their services began to be sought not only by traders in Ariaria and other major markets in the Southeast but by residents and other major stakeholders in the region (Jones, 2008, 2).

Given the context through which the group emerged, the original aim was to fight armed robbery and other violent crimes but with its hijack by the Governors and other powerful individuals in the Southeast, the original goal of the outfit became diluted, resulting in its politicization (Tertsakian, 2002). At this stage, the group now christened 'political' Bakassi Boys became the tool in the hands of the State Governors. In Anambra State, for example, prior to the formal endorsement of the Bakassi Boys', by the administration of Dr. Chinwoke Mbadiniju, in 2002, the vigilante sector in the state, for years, had been dominated by the Onitsha Traders Association (OTA) which was formed by traders in Onitsha, in the early I990s. However, by the advent of democracy in Anambra State, in I999, OTA became less popular with the people as a result of its methods and thus paving way for the emergence of the Bakassi Boys, to take the center stage.

In August 2002, Governor Mbadiniju formally endorsed the group, by sending a bill to the State House of Assembly for consideration. In December the same year, the bill, having been passed by the legislature and signed by the governor, became the Anambra State Vigilante Service Law, No. 9 of year 2000 (HRW/CLEEN, 2002, IO). With the coming into force of this law, the Bakassi Boys of Anambra State, officially, became the Anambra Vigilante Service (AVS) to be maintained and supervised by the Government of Anambra State. As reported by the Amnesty International $(2002,8)$, 'the Anambra State Vigilante Service is the first - and to date only - armed vigilante group officially recognized by a state government in Nigeria through a bill enacted by the State Governor'. Interestingly, similar experiments were undertaken in other Southeastern states of Abia, Imo and Ebonyi States. The only except 
was Enugu state where the Governor insisted that the existing system of public policing was adequate to guarantee security (Akubor, 20I4,3I). It must be emphasized here that the Bakassi Boys, irrespective of the names that were called in these states, before being proscribed with other similar armed groups in different parts of the country, operated with reckless abandon, killing and maiming of people in the name of crime fighting. Perhaps, it was the totality of these inhuman activities and other malfeasance coupled with the negative press that they were giving the country in the comity of nations that the group, despite the protestations of the Southeast Governors, was proscribed by the Federal Authorities in 200I.

\section{The O'odua People's Congress (OPC)}

The O'odua People's Congress (OPC), a group dominant in the Southwestern part of Nigeria, the geographical base of the Yoruba ethnic group, was initially formed on August $24^{\text {th }}$, I994, at Mushin, Lagos, by seven individuals, all Yoruba origin, led Dr. Fredrick Fasehun. It did not start as a vigilante group but as a self-determination-oriented group to protect and defend the interests of the Yorubas in the Nigerian project (Fasehun, 2002, I59). Specifically, it arose against the background of the injustice meted out to a prominent Yoruba son, Chief Moshood Abiola and by extension, the Yoruba race, following the annulment of the I993 presidential election, won by Abiola, by the military regime of General Ibrahim Babangida. However, it must be stressed that it emerged, albeit, not to restore Abiola's stolen mandate in pristine form, but rather, to prevent the recurrence of another June $12{ }^{\text {th }}$ episode (Fasehun, 2002, I59, I60).

However, by I999, the group, due to rising crime rates in the major cities of the Southwest and the seeming impotence of the Nigerian police to arrest them, added crime fighting to its foundational objective of being an ethnic champion. In the words of Fasehun (2002, I2) 'fighting crime is not one of the objectives of OPC but when the crime became so high that people were living virtually in fears, OPC took a diversion, mark my word, took a diversion, from its primary aims and objectives to assist the police to fight crimes, secure life and property'. Instructively, crime fighting soon overshadowed the other objectives of the group. Avers Fasehun (200I, 5):

As a matter of fact, OPC fights crime. Various times, they have arrested criminals and hands them over to the law enforcement agents. And 
if you are planning to join OPC, one of the things you are made to swear to is that you will assist in the prevention of crime.

Operationally, like most indigenous-oriented groups, steeped in spiritualism and fetishism, OPC deploys traditional occultism to fighting crime. For instance, members of the group often consult oracle to determine the future on any particular course of action (see Adebanwi, 2005). Also, members of the group wear black clothing and often speak in coded languages which cannot be deciphered by those outside the group (Owumi, 20I3,78). According to Human Rights Watch (2003), 'members of OPC were often kitted with occult, 'insurance cover' by incisions, gbere, on their bodies with charms. This emboldened them in the discharge of their vigilante duties'.

Notwithstanding these, the group, especially, in the first few years of the country's return to democracy, gained so much popularity and acceptability among the people of the southwest. Indeed, in major cities in the region, the group, because of its audacity to venture into the dens of criminals which the police for years dared not to venture into, became the courted bride of the people (Ajayi; Aderinto, 2008, 2012). As Babawale $(2003,62)$ notes, 'the OPC in the southwest literally became a parallel security outfit with its involvement in vigilante services and its running battle with criminal gangs'. However, like the Bakassi Boys, examined earlier, OPC, in discharging vigilante services, engaged in activities, that most times, threatened public order.

It clear from the foregoing discussions that the activities of vigilante groups in democratizing societies could be anti-social and as such could have implications on the country's security environment.

\section{Vigilante Groups and National (In)security in Post-Authori- tarian Nigeria}

In the contemporary mass society, no country, due to a combination of factors, is able to fight crime effectively only through public policing without the supports of sub-state actors. But, in liberal jurisdictions, while vigilante groups often operate within the perimeter of rule of law and constitutionalism, their counterparts in illiberal democracies, as the case of the post-Authoritarian Nigeria being examined in this study will soon show, tend to operate in manner that do not only put question mark on the entire concept of vigilantism but also constitutive threats to social stability and by extension, the security of the society (see Oronsaye; Igbafe, 20I2). 
Although, it has to be stressed that while some vigilante groups, especially, those organized as neighborhood watches, in major cities, across the country, have to a reasonable degree, tended to mimic vigilantism in liberal jurisdictions, most vigilante groups, in Nigeria, especially those that arose in the atmosphere of what Lumumba-Kasongo $(1995,409)$ referred to as 'anger', 'conflict' and 'irrationality', in the last few years, have been antithetical to established norms of vigilantism and by implications, constitute threats to social stability. There are several reasons for this. In the first place, most vigilante groups in contemporary Nigeria hardly operate in conjunction with the police as is the situation in matured democracies. Even where the vigilante groups are mandated by law to work with the police, in dealing with suspects, most of them rather than working with the police, would still resort to self-help measures. In Anambra State, for example, the law that gave legality to the activities of the Bakassi Boys, states that the vigilante group shall augment the maintenance of security in their various community and shall in particular render all lawful help and assistance to the police in the sphere of crime prevention and detection (ANSG, 2000).

These clear mandates, notwithstanding, the Bakassi Boys, before they were proscribed by the Federal Government, in practice, rarely if ever render all lawful help and assistance to the police in the state (HRW/CLEEN, 2002, I3). The same remark could be made of OPC and other vigilante groups that operate at the communal levels. In bringing crime suspects to justice, these groups created detention and torture camps that look like Kangaroo police stations, courts and prisons where suspects are arbitrarily interrogated, detained, tried, tortured and summarily executed or fined (Owumi, 20I3, 79).

All these extra-judicial measures by vigilante groups in the last few years, whether reported or not, aside impinging on the human right sector, have led to the proliferation of small arms and light weapons in the country as these groups, including those that have recently sprung up, have been the greatest patronizers of illicit arms. With regard to the human rights sector, vigilante violence often leads to the violation of the individual and group rights of the people (Anyanwu, 2007). Indeed, this often assume graver dimension when group rights are violated by a vigilante group as this often lead to reprisal attacks. For example, in I999, barely a year to the return to democracy, the reprisal killing of the Yorubas in Kano, was generally perceived to be a reaction to the violation of the rights to life and property of the Hausas by the OPC in Sagamu. Indeed, the reprisal attack in Kano did not result in the killing of only the Yorubas but also the killings of Ibo, which in turn led to reprisal attacks on the Hausa/Fulani group resident in Aba and some eastern states, which all resulted in loss of lives and property (Akinyele, 200I). 
Directly related to the foregoing is the legacy of violence that the formation of OPC, Bakassi Boys and other militant vigilante groups have brought upon the country. To be sure, they have either triggered a number of violent ethnic movements and by implications, ethnic conflicts across the country or it has had militarizing effects on some existing movements. Specifically, Ikelegbe $(2005,496)$ contends that the emergence of the Arewa People Congress (APC) was a reaction to the activities of the OPC, particularly attacks on Hausa in the southwest. Even within the Yorubas' geo-political space, Ajala (2006, I3I,I4I) posits that groups, such as the Oodua Liberation Movement (OLM), Oodua Youth Movement (OYM) and Oodua Republic Front (ORF) that share similar ideology with OPC were triggered into existence as a result of the activities of the OPC.

The point being made is here is that the repugnant and uncivil activities of vigilante groups like the OPC attracted other groups to join the vigilante sector, with the result that vigilante violence percolated virtually everywhere. For example, in 2005 , vigilante violence perpetuated by a local vigilante group in Ago-Iwoye, Ogun State, Southwest Nigeria, against the students of the Olabisi Onabanjo University, in which many students lost their lives, led to counter-attacks from the students. Indeed, the crisis did not only lead to the closure of the university but also a dusk to dawn curfew was imposed on the whole town by the Government of Ogun State, in order to reduce further human carnage. Another worrisome aspect of the activities of vigilante groups in the last few years is their politicization by the dominant political actors, especially, during elections. For instance, the Bakassi Boys, as reported by major international human rights advocacy groups, was used by the Southeastern Governors to harass and intimidate their perceived political opponents in the run to the 2003 governorship election in the region (HRW/ CLEEN, 2002,I2).

Linked to the above is the increasing outsourcing of policing to some militant vigilante groups in the country by the Federal and State Governments, a development which reached its zenith under the presidency of Dr. Goodluck Jonathan, when militant groups like the Niger Delta Volunteer Force and the OPC were given contracts and licenses to police the country's strategic assets in the Niger Delta. Indeed, this state of affairs to some concerned citizens was not only seen as constituting a threat to the security of the country and the concerned communities but also seemed to have downed the morale of the officers and men of the military and paramilitary forces. The issue here is that by investing in informal groups, with little or no training in arms handlings, with the roles that ought to be performed by the military and paramilitary forces, an atmosphere of insecurity and rights violation is 
created by the government. For example, in an operation carried out by OPC to flush out pipeline vandals, around Arepo area, in Ogun State, Southwest Nigeria in early 2015, aside from not achieving the intended objectives, led to loss of innocent lives and destruction of properties.

\section{Conclusions}

This article set out to examine the character of vigilante groups in a democratizing Nigeria against the backdrop of the contradictory views about their roles. In furtherance of this objective, it clarified key concepts relevant to the discourse, examined extant literature on vigilantism and vigilante groups in Nigeria and assesses the balance sheet of vigilante groups in a democratizing Nigeria. From these reviews and analyses, it found that the character of vigilantism and vigilante groups in Nigeria is markedly different from those in liberal jurisdictions. It also notes that unlike the practice in liberal democracies where vigilante groups, in conduct and practice, conform to principles of rule of law and constitutionalism; the opposite, going by the activities of some militant vigilantes since the return of democracy, is the case. This state of affair has impacted negatively on the country's security environment. In the light of these, it argues and concludes that as long as the vigilante groups, like the formal policing establishments, remain the instruments of political intimidation of political opponents by the politicians that control them, the terrain of vigilantism would continue to be in the realm of 'anocracy'.

\section{References}

Adamu, F. 2008. "Gender, Hisba and the Enforcement of Morality in Northern Nigeria". Africa, 78, I, I36 I52.

Adebakin, K. and Raimi, L. 20I2 "National Security Challenges and Sustainable economic Development: Evidence from Nigeria”. Journal of Studies in Social Sciences Volume I, Number I.

Adebanwi, W. 2005. "The carpenter's revolt: youth violence and the reinvention of culture in Nigeria."Journal of Modern African Studies 43, 3.

Ahire, P. T. I99I. Imperial Policing: The Emergence and Role of the Police in Colonial Nigeria. Philadelphia: Open University Press. 
Ajala A.S 2006. "Cultural nationalism, Democratization and Conflict in Yoruba Perspectives: focus on Oodua Peoples' Congress in Nigerian Politics". Studies in Tribes and Tribals 4(2).

Ajayi, J. O and Aderinto, A.A. 2012. Oodua People's Congress and Crime Control In Lagos Metropolis. Germany: LAP Lambert Academic Publishing.

Ajayi, J.O. and Aderinto, A.A. 2008. "Crime Wave and Public Confidence in Oodua People's Congress in Lagos Nigeria”. African Journal for the Psychological study of Social Issues, Vol. II (2).

Akinyele, R. T. 200I. "Ethnic Militancy and National Stability in Nigeria: A Case Study of the Oodua People Congress". African Affairs, Ioo.

Akubor, E.O (20I4). "An Outline of Ethnic Militias in Nigeria”. Constitution, Vol 4 (2), June.

Akuul, T. 20II. "The Role of the Nigerian Police Force in Maintaining Peace and Security in Nigeria" Journal of Social Science and Public Policy, Vol 3, March.

Alemika, E. and Chukwuma, I.C 2004. The Poor and Informal Policing in Nigeria: A Report on the Peoples' Perceptions and Priorities on Safety, Security and Informal Policing in the A2J Focal States in Nigeria. Lagos: CLEEN.

Alemika, E. and Chukwuma, I.C. 2004. Analysis of Police and Policing in Nigeria: A desk Study on the Role of Police as a Barrier to Change or Driver of Change in Nigeria. Lagos: CLEEN.

Amnesty International. 2002. Nigeria: Vigilante violence in the south and southeast. London: Amnesty International.

ANSG. 2000. Anambra State Vigilante Services Law, no.9, 2000, Official Gazette. Awka: ANSG.

Anyanwu, G. 2007. "Tyranny of vigilance group: They brutalize residents over illegal levies", Daily Sun, February 28.

Babawale, T. 2003. "The state, ethnic militias and the challenges of democratic governance in post military Nigeria". In: Urban violence, ethnic militias and the challenge of democratic consolidation in Nigeria edited by Babawale. T. Lagos: Malthouse Press.

Baker, B. 2002. "When the Bakassi Boys came: Eastern Nigeria Confronts Vigilantism". Journal of Contemporary African Affairs, 20, 223244.

Baker, B. 2008. Multi Choice Policing in Africa. Uppsala: Nordic Africa Institute. 
Basiru, A. S 20I6. The Travails of Domesticating 'Liberal Peace' in West Africa: Nigeria and the 2001 ECOWAS Supplementary Protocol on Democracy and Good Governance, Paper presented at a 2-Day National Conference, organized by the Aminu Kano Centre for Democratic Research and Training, Bayero University, Kano, November 9-Io.

Bayley, D. H. 2006. Changing the Guard: Developing Democratic Police Abroad. New York: Oxford University Press.

Chukwuma, I. I998. "Police Powers and Human Rights in Nigeria", Law Enforcement Review. Lagos, January-March.

Chukwuma, I. 2002. "Responding to Vigilantism", Human Rights Dialogue, Series 2, No. 8.

Fabiyi, S. 2004. Gated Neighbourhoods and Privatization of Urban Security in Ibadan Metropolis. Ibadan: Institut Français de Recherche en Afrique.

Fasehun, F. 2002. Son of Oodua. Lagos: Inspired Communication.

Fasehun, F. 200I. "OPC will unite again” Newswatch (Lagos), September Io.

Federal Government of Nigeria (I990) Police Act CAP 359 of the Laws of the Federation of Nigeria. Lagos: Government Press

Fourchard, L. 20II. "The Politics of Mobilization for Security in South African Townships" African Affairs iıo, no. 44I.

Gallie, W.B. I962. "Essentially Contested Concepts" in The Importance of Language. edited by Black, M. New Jersey: Prentice Hall Press.

Harnischfeger, J. 2003. “The Bakassi Boys: fighting crime in Nigeria”, Journal of Modern African Studies 4I (I).

Higazi, A. 2008. "Social Mobilization and Collective Violence: Vigilantes and Militias in the Lowlands of Plateau State, Central Nigeria", Africa, 78 , I.

HRW. 2003. The OPC: Fighting violence with violence. New York: Human Rights Watch.

HRW/CLEEN. 2002. The Bakassi Boys: The Legitimatization of Murder and Torture. New York: Human Rights Watch.

Ikelegbe, A. (2005) "State, ethnic militias and conflict in Nigeria", Canadian Journal of African Studies, 39(3), 490-516

Ikoh, M.U. 20I3. "The Interface of Formal and informal Policing Structures in Calabar Metropolis: Implication for Community Policing in Nigeria”. Journal of Power, Politics a Governance, Vol. I No. I, December. 
Jemibewon, D. 200I. "The Nigerian Experience" in Crime and Policing in Transitional Societies. edited by Shaw, M. Johannesburg: Konrad Adenauer Stiftung and South African Institute of International Affairs.

Jemibowon, D. M. 2003. The Nigeria Police in Transition: Issues, Problems and Prospects. East Lansing: Michigan State University Press.

Johnston, L. 1992. The Rebirth of Private Policing. New York: Routledge.

Jones, R. 2008. State failure and extra-legal justice: vigilante groups, civil militias and the rule of law in West Africa, Research Paper No. I66. London: School of Oriental and African Studies, University of London.

Kwaja, C. 20I4.Informal Security Provision in Nigeria: Implications for Security Sector Governance. Kitchener: Security Sector Reform Centre.

Lar, J.T. 20I5. Vigilantism, state and society: A history of plural policing in plateau state, Nigeria, I950 to the present. (Doctoral Thesis, Bayreuth International Graduate School for African Studies (BIGSAS), University of Bayreuth Germany

Loader, I. 2000. "Plural Policing and Democratic Governance", Social and Legal Studies, 9, 3.

Lumumba-Kasongo, T. I995. "Social Movement and the quest for Democracy in Africa: MOJA and its Transformation into a Political Party" in African Studies in Social Movements edited by Mamdani, M. and Wamba-dia-Wamba, E. Dakar: CODESRIA Books.

Nigerian Tribune.I987. April $7^{\text {th }}$.

Nwanze, S. I999.In Thy Hands oh God: The Man, the Cop, the Preachet. Lagos: Nio Publishers

Obasanjo, O. (I999) Inaugural speech by His Excellency, President Olusegun Obasanjo following his swearing-in as President of the Federal Republic of. Nigeria. Retrieved from http://nigeriaworld.com/feature/speech/inaugural.html/accessed 02/02/2018

Ogbozor, E. 2016. Understanding the Informal Security Sector in Nigeria, Special Report 39I. Washington: United States Institute of Peace, September.

Ojo, E.O. 2004. "The Military and Political Transition” in Nigeria's Struggle for Democracy and Good Governance edited by Adigun Agbaje etal. Ibadan, Ibadan University Press. 
Oronsaye, A. and Igbafe, A. 20I2 "Ethnic Militia in Nigeria: An Assessment of the Terrain of Conflicts, Violence and Crime". African Journal of Social Sciences, Volume 2 Number I.

Otto, G. and Upkere, W. I (20I2). "National Security and Development in Nigeria". African Journal of Business Management, 6 (23), p. 6765 6770.

Owumi, B. 20I3. "Traditional Values, Beliefs and Reliance on Indigenous Resources for Crime Control in Modern Southwest Nigeria”. African Research Review, 7(I).

OYSG. I987.Mobilisation Community Development Committee Edict, 1987: Supplement to the Oyo State of Nigeria, Gazette $n^{\circ}$ I4, vol. I2 of 2 April. Ibadan: OYSG

Pratten, D. 2008. "Perspectives on Vigilantism in Nigeria”. Africa: Journal of the International African Institute, 78 (I), pp. I-I5

Rotimi, K. 200I. The Police in a Federal State: The Nigerian experience. Ibadan: College Press).

Shaw, M. 2000.Crime and Policing in Transitions: Comparative Perspectives, Johannesburg:

South African Institute of International Affairs

Smith, D. J. 2004. "The Bakassi Boys: vigilantism, violence and political imagination in Nigeria", Current Anthropology I9 (3).

Soanes, C. 2001.Oxford Dictionary of Current English. Oxford/New York: Oxford University Press.

Tamuno, T. I970. The Police in Modem Nigeria 1861-1965. Ibadan: University Press Ibadan.

Tamuno, T. et al. I993. Policing Nigeria, Past, Present and Future. Lagos: Malthouse Press Limited).

Tertsakian, C. 2002. The Bakassi Boys: The Legimation of Murder and Torture, New York: Human Rights Watch and the Centre for Law Enforcement Education.

Umede, H. 20II. "Nigeria: Analyzing the Security Challenges of the Goodluck Jonathan Administration". Canadian Social Science Vol. 7, No. 5 .

Watson, R. 2003. Civil Disorder is the Disease of Ibadan, Chieftaincy and Civic Culture in a Yoruba City, Oxford: James Currey 
Wisler, D. and Onwudiwe, D. I 2005. Editorial: Plural Policing in Africa, International Police Executive Symposium Working Papers Series, No 6-Io).

\section{ABSTRACT}

In the last few years, vigilante groups and other informal policing structures have assumed a greater role in the security architecture of many countries, especially those that exited from authoritarian order. In spite of this development, however, issues and concerns are constantly being raised about them regarding whether they could really be agents of democratic policing against the backdrop of their penchant for human rights violations and extra-judicial killings. It is against this background that this article examines the balance sheet of vigilante groups in a democratizing Nigeria. Following an extensive review of extant literature on police, policing, vigilantism and vigilante groups, as well as relevant studies on vigilante groups in Nigeria, it observes and notes that unlike the practice in liberal democracies, where vigilante groups - in conduct and practice - conform to principles of rule of law and constitutionalism, the opposite is the case in a democratizing Nigeria. It argues and concludes that as long as the vigilante groups, like the formal policing establishments, remain the instruments of intimidation of political opponents by the politicians that control them; the terrain of vigilantism would continue to be in the realm of 'anocracy'.

\section{KEYWORDS}

Vigilantism; Vigilante groups; Authoritarianism; Police; Policing; Democracy.

Received on June 27th 2019 Accepted on July 28th 2019 